\title{
Ovarian Ultrasonographs, Milk Progesterone Profiles, hCG Treatment and Sexual Behavior for Better Diagnosis of Ovarian Follicular Cysts in Cows
}

\author{
Yutaka Sawamukai, Masako SaItoh, Toshihiko NakaO, ${ }^{1)}$ and Keiichiroh Kawata ${ }^{1)}$ \\ Veterinary Clinic and Training Center, Federation of Hokkaido Agricultural Mutual Rerief Association, Motonopporo 612, \\ Ebetsu, Hokkaido 069 and "Department of Veterinary Obstetrics and Gynecology, Rakuno Gakuen University, Bunkyodai- \\ Midorimachi 582-1, Ebetsu, Hokkaido 069, Japan
}

(Accepted for publication February 2, 1991)

\begin{abstract}
Summary. Sixteen Holstein cows with ovarian follicular cysts diagnosed by rectal palpation were used to correlate changes in ultrasonographic image of the ovaries, sexual behavior and skim milk progesterone profiles. Of 16 cases, 4 cows exhibited typical nymphomaniac symptoms, 3 had recurrent nymphomaniac symptoms, and the remaining 9 showed anestrus. Neither corpora lutea nor luteal tissues on the cystic wall were detected by ultrasonography during a 20 days of observation period. On the 20 th day the animals were treated with hCG $10,000 \mathrm{IU}$. Following hCG treatment, 5 of the 7 nymphomaniac cows no longer showed the symptoms and 3 of the 7 cows showed the formation of corpora lutea or luteal cysts, while 6 of the 7 cows showed an upward tendency of skim milk progesterone levels. Of the 9 anestrous cows, 7 cows responded to hCG with an increase in skim milk progesterone levels and luteinization of co-existing medium-sized follicles and newly-formed follicular cysts. The results indicate that ultrasonography in addition to careful observation of sexual behavior and skim milk progesterone measurement is helpful for an accurate diagnosis of bovine ovarian follicular cysts.

KEY WORDS: COW, OVARIAN FOLLICULAR CYSTS, ULTRASONOGRAPHY, SEXUAL BEHAVIOR, SKIM MILK PROGESTERONE
\end{abstract}

Jpn J Anim Reprod 37, 167-175, 1991

Cystic degeneration of the ovarian follicles is still one of the major reproductive disorders in cattle. The ovarian follicular cysts are characterized by the presence of one or more follicles larger than $2.5 \mathrm{~cm}$ in diameter for 10 days or longer without co-existence of the functional corpus luteum (Seguin, 1980). Observation of abnormal sexual behavior, irregularity in the estrous cycle and rectal palpation for the presence of follicular cysts in the ovary have been the basis for the clinical diagnosis of this disease. In recent years, however, many cases of follicular cysts are diagnosed in anestrous cows by rectal palpation. A wrong diagnosis is often led only by rectal palpation (Sawamukai et al., 1986). For the differential diagnosis of follicular cyst and luteal cyst or cystic corpus luteum, milk progesterone measurement has been proved to be useful (Nakao et al., 1983). Milk or peripheral blood progesterone levels, however, may not always reflect the clinical symptoms of the cows with follicular cysts (Kohmoto, 1987 ; Nakao, 1976 ; Sawamukai et al., 1984). Recent advances in clinical application of ultrasonography have made more accurate observation of the ovarian morphology possible (Edmondson et al., 1986). It may be worthy to apply the ultrasonography to diagnose accurately the ovarian follicular cysts.

\section{Materials and Methods}

\section{Animals}

Sixteen cows with ovarian follicular cysts 
were diagnosed by palpation through rectum as having one or more follicles or follicular structures, larger than $2.5 \mathrm{~cm}$ in diameter, were used. The animals were kept as usual at commercial dairy farms located in the central part of Hokkaido in Japan. The average body weight and milk yield for a 305-days lactational period in these herds were approximately $720 \mathrm{~kg}$ and $7,800 \mathrm{~kg}$, respectively. The ages of the cows and the intervals between calving and diagnosis of the cysts ranged between 2 - 9 (5 \pm 2 ; mean \pm SD) years and $46-231(127 \pm 57)$ days.

Of the 16 cows, 4 exhibited nymphomania for 10 days or longer before the clinical examination, 3 other cows showed interrupted nymphomania and the remaining 9 cows were anestrus after the last parturition or artificial insemination.

\section{Observation of sexual behavior}

The cows with follicular cysts were checked for sexual activities at an interval of 5 days; on each day, the cows were observed at 6:00 - 9:00 a.m. and 4:00 - 6:00 p.m.

\section{Ultrasonography}

Ultrasonographic observation was conducted at an interval of 10 days, beginning with the day of detection of follicular cysts by rectal palpation. An ultrasonic liner electronic system attatched with a digital scan converter (Aloka Echo Camera SSD-246 and SSD-630, Co., Ltd., Tokyo) was used in this experiment. The diameters of most of the various follicles and the longest and widest points of the corpus luteum were measured by comparison with the $1.0 \mathrm{~cm}$ scale along the edge of the image.

\section{Milk progesterone measurement}

Milk was sampled before the morning milking, from one or more udder quarters daily for 30 days experimental period. Milk samples were kept at $-20{ }^{\circ} \mathrm{C}$ and, before analysis for progesterone, were thawed and defatted by centrifugation $(3,000 \mathrm{rpm}, 10$ min). Progesterone concentration in defatted milk was determined by enzyme immunoassay as reported by Nakao et al. (1983).

\section{Treatment}

The cows were treated with an intramuscular injection of $10,000 \mathrm{lU}$ of human chorionic gonadotrophin, hCG (Gonatropin, Teikoku Hormone MFG. Co., Ltd., Tokyo) on day 20 of the experiment.

\section{Results}

\section{Sexual behavior}

The 4 cows which had been showing nymphomaniac symptoms before the experiment continued to exhibit the symptoms during 20 days of the observation period. Following hCG treatment, two of the 4 cases responded to the treatment and nymphomaniac symptoms disappeared on day 5 . The other 3 cows having a history of intensive irregular-cycled sexual behavior also exhibited nymphomania around day 10 of the experiment. All of the 3 cases responded to hCG injection and did not show any symptoms of nymphomania after treatment. The 9 anestrous cows maintained anestrus for 30 days of the experiment except for one case which came into normal estrus 7 days after hCG treatment (Table 1).

\section{Ultrasonographs}

Changes of ultrasonograph of ovaries with cystic follicles were summarized and are shown in Table 2. Dynamic changes in ovarian morphology including the development and regression of cystic follicles and co-existing medium-sized follicles were recognized in 4 nymphomaniac cows before and after treatment. On 10 days after hCG treatment, in 3 of the 4 cows neither corpora lutea nor luteal tissues on the cystic wall were detected by ultasonography, while in one cow corpus luteum with a central cavity became visible (Fig. 1). 
Table 1. Changes in sexual behavior checked twice a day during the experimental period in cows with ovarian follicular cysts

\begin{tabular}{|c|c|c|c|c|c|c|c|c|}
\hline \multirow{2}{*}{ Symptoms } & \multirow{2}{*}{ No. of cases } & \multicolumn{7}{|c|}{ Observation day of sexual behavior } \\
\hline & & 0 & 5 & 10 & 15 & 20 & 25 & 30 \\
\hline Nymphomania & 4 & 4 & 4 & 4 & 4 & 4 & 2 & 2 \\
\hline Interrupted nymphomania & 3 & 0 & 0 & 3 & 3 & 3 & 0 & 0 \\
\hline Anestrus & 9 & 0 & 0 & 0 & 0 & 0 & 0 & 0 \\
\hline
\end{tabular}

Notes: 1) All of the cows were treated intramuscularly with 10,000 IU of hCG on 20 days after the first observation. 2) One case in anestrous cows (Cow No. YC) came into normal estrus 7 days after hCG treatment.

Table 2. Changes of ovarian follicular cysts and co-existing Graafian follicles observed by ultrasonography during the experimental period in cows with ovarian follicular cysts

\begin{tabular}{|c|c|c|c|c|c|}
\hline \multirow{2}{*}{$\begin{array}{c}\text { Group } \\
\text { (No. of cases) }\end{array}$} & \multirow{2}{*}{$\begin{array}{l}\text { Ultrasonic image } \\
\text { of ovaries }\end{array}$} & \multicolumn{4}{|c|}{ Days after the first observation } \\
\hline & & 0 & 10 & 20 & 30 \\
\hline \multirow{4}{*}{$\begin{array}{l}\text { Nymphomania } \\
\qquad(\mathrm{n}=4)\end{array}$} & $\mathrm{FC}$ & 1 & 1 & & \\
\hline & $\mathrm{FC}+\mathrm{rFC}+\mathrm{GF}$ & & 1 & 4 & 3 \\
\hline & $\mathrm{FC}+\mathrm{GF}$ & 3 & 2 & & \\
\hline & $\mathrm{rFC}+\mathrm{GF}+\mathrm{CL}$ & & & & $1(1)$ \\
\hline \multirow{6}{*}{$\begin{array}{c}\text { Interrupted } \\
\text { nymphomania } \\
\quad(\mathrm{n}=3)\end{array}$} & FC & 1 & & & \\
\hline & $\mathrm{FC}+\mathrm{rFC}+\mathrm{GF}$ & & & 2 & \\
\hline & $\mathrm{FC}+\mathrm{GF}$ & 2 & 3 & 1 & \\
\hline & $\mathrm{rFC}+\mathrm{GF}$ & & & & 1 \\
\hline & $\mathrm{rFC}+\mathrm{GF}+\mathrm{CL}$ & & & & $1(1)$ \\
\hline & $\mathrm{CL}$ & & & & $1(1)$ \\
\hline \multirow{8}{*}{$\begin{array}{l}\text { Anestrus } \\
\quad(n=9)\end{array}$} & $\mathrm{FC}$ & 1 & 1 & 2 & \\
\hline & $\mathrm{FC}+\mathrm{rFC}+\mathrm{GF}$ & & 3 & 4 & \\
\hline & $\mathrm{FC}+\mathrm{GF}$ & 8 & 5 & 3 & \\
\hline & $\mathrm{rFC}+\mathrm{GF}$ & & & & 2 \\
\hline & $\mathrm{FC}+\mathrm{rFC}+\mathrm{GF}+\mathrm{CL}$ & & & & 1 \\
\hline & $\mathrm{FC}+\mathrm{GF}+\mathrm{CL}$ & & & & $3(2)$ \\
\hline & $\mathrm{rFC}+\mathrm{GF}+\mathrm{CL}$ & & & & $2(2)$ \\
\hline & $\mathrm{GF}+\mathrm{CL}$ & & & & $1(1)$ \\
\hline
\end{tabular}

Notes:

1) Characterization of ultrasonic image of follicles and corpora lutea as follows;

FC(Follicular cyst): Follicular structure $2.5 \mathrm{~cm}$ in diameter or larger.

rFC (Regressive follicular cyst): Smaller than $2.5 \mathrm{~cm}$ in diameter.

GF (Medium-sized follicle): $1.0-2.4 \mathrm{~cm}$ in diameter. CL (Corpus luteum): Luteinized follicle, $1.5 \mathrm{~cm}$ in longest and widest points or larger.

2) Number in parenthesis shows the cows having Luteal cyst with central cavity luteinized follicle.
In 2 of 3 cows with interrupted nymphomaniac symptoms, follicular cysts with $\mathrm{co}^{-}$ exising medium-sized follicles were detected on the first observation day. These follicular cysts and co-existing follicles showed variable morphological changes and a new follicular cyst or medium-sized follicle developed on day 10 or day 20 in all cases. Luteinization of variable follicles was detected by ultrasonograpy on day 10 after treatment in 2 cases.

In the 9 anestrous cows, 8 cows had follicular cysts and co-existing medium-sized follicles, but one case had follicular cysts only in the first observation day. On 10 days after hCG treatment, no follicular cysts and regressive follicular cysts were observed to have luteinized, while co-existing mediumsized follicles or newly-formed follicular cysts showed an image of the luteinization in 7 cows (Fig. 2).

In two cows, one from nymphomania group and one from anestrus group, the ultrasonographs of the ovaries are shown in Figs. 1 and 2 respectively.

\section{Skim milk progesterone profiles}

Skim milk progesterone profiles in cows with follicular cysts showing different sexual behavior are presented in Fig. 3. Two of the typical nymphomaniac cows and 2 of the interrupted nymphomaniac cows showed an irregular fluctuating pattern of skim milk progesterone levels before hCG treatment. After hCG treatment in 6 cows of both groups, skim milk progesterone levels 


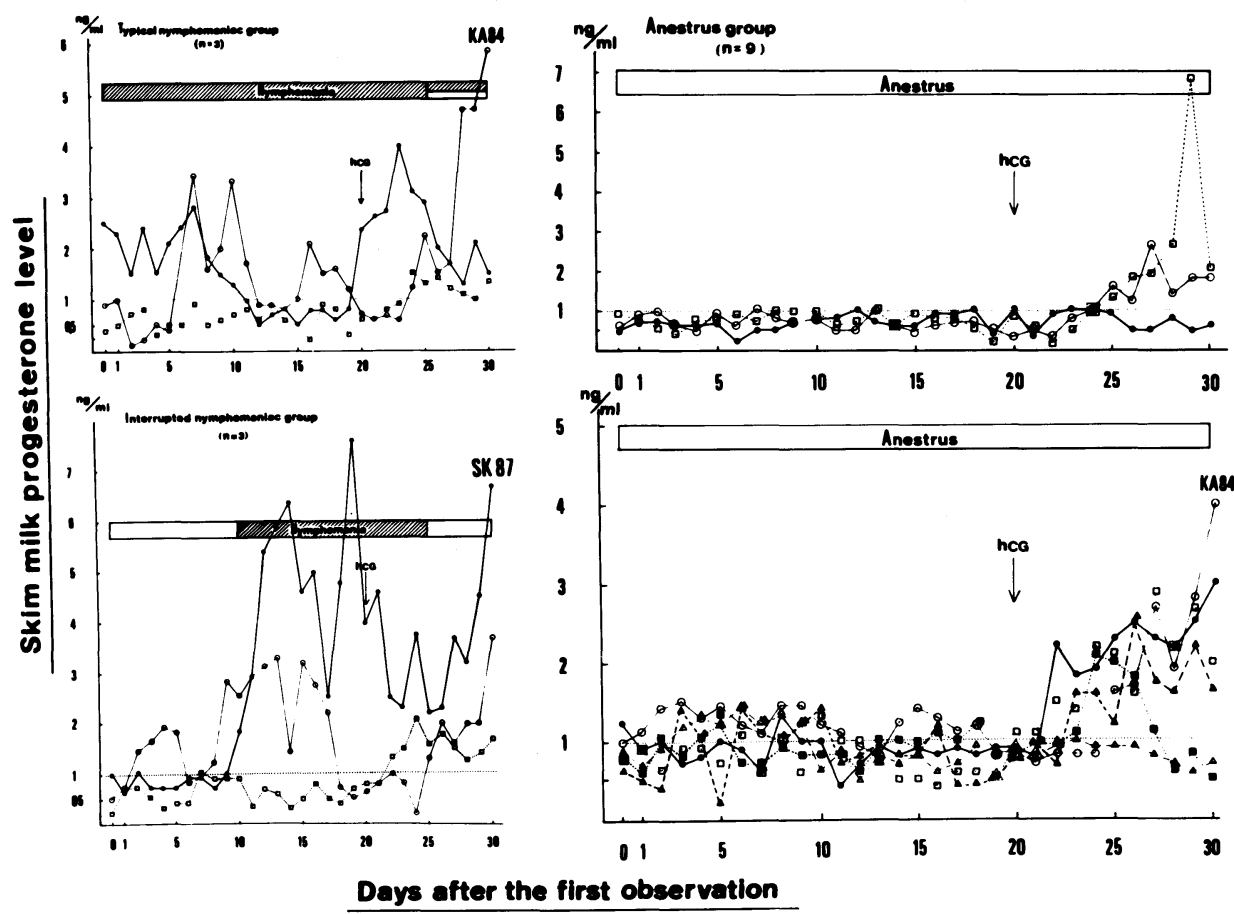

Fig. 1. Changes in skim milk progesterone levels in 4 typical nymphomaniac, 3 interrupted nymphomaniac and 9 anestrous cows with follicular cysts before and after treatment.

Note. $\downarrow$ : Treated with 10,000 IU hCG intramuscularly.

showed an upward tendency. The 9 anestrous cows did not show a significantly fluctuating pattern before treatment, after hCG treatment 7 of the 9 cows showed an increase of skim milk progesterone levels up to $1.0 \mathrm{ng} / \mathrm{ml}$ or higher.

\section{Discussion}

In this experiment, 2 of the 4 cows exhibiting nymphomaniac symptoms showed an irregularly fluctuating pattern of skim milk progesterone levels for 20 days before hCG treatment, whereas these cows had neither corpora lutea nor luteal tissues in the cyst wall. After hCG treatment, in 3 of the 4 cows, skim milk progesterone levels increased. However only one case of them showed luteinization of a new cyst and medium-sized follicle. Likewise, in 2 of the 3 cows exhibiting interrupted nymphomaniac symptoms, skim milk progesterone profiles showed variable fluctuating patterns, and neither corpora lutea nor luteal cysts were observed before hCG treatment. In all the 3 cases, skim milk progesterone levels showed an upward tendency. The increase of skim milk progesterone levels was associated with the formation of corpus luteum following hCG treatment in 2 cows, but not in one cow. Thus, some cows with nymphomaniac symptoms showed high progesterone levels, without having functional corpora lutea. Abnormal sexual behavior often found in cows with ovarian follicular cysts may be caused mainly by estrogens and progesterone secreted from the ovaries (Short, 1962). Continuous or short-cycling irregular nymphomania may be considered as the consequence of prolonged secretion of estrogens and androgens from follicular cysts or coexisting Graafian follicles which developed one after another as demonstrated in the 


\section{Days after the first observation}

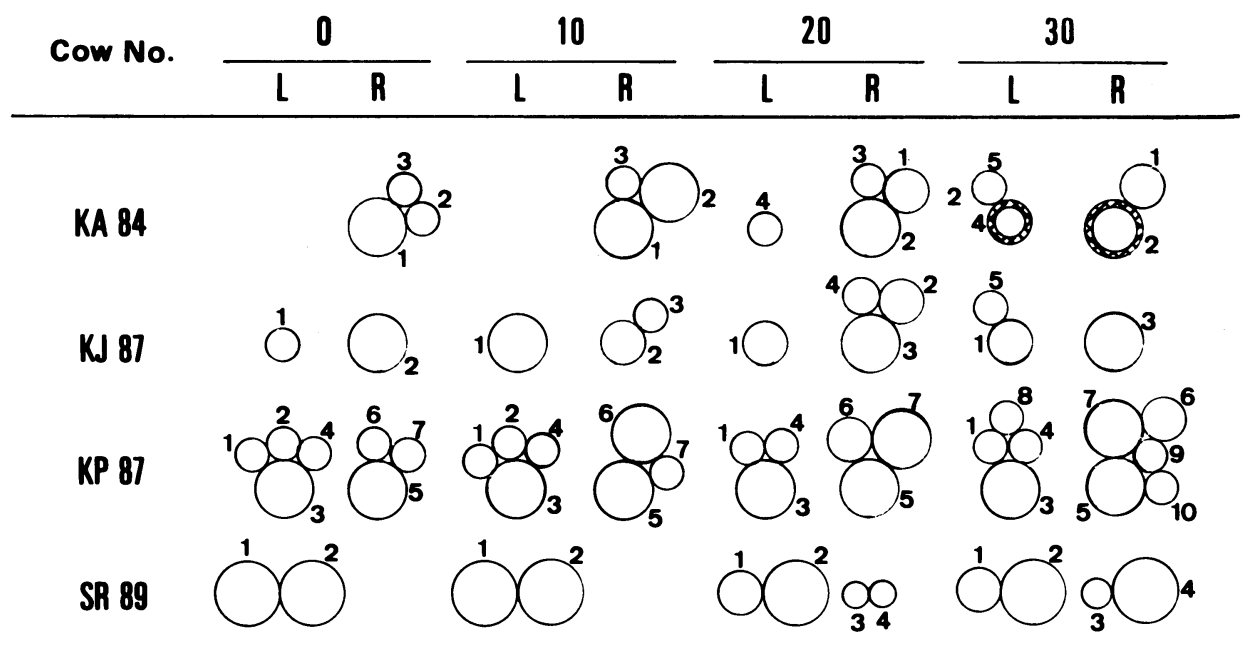

Fig. 2. Ultrasonographic schemata of follicular and luteal structures in ovaries of 4 cows wth typical nymphomania before and after treatment.

Notes. 1) The cows were treated intramuscularly with 10,000 IU of hCG at day 20 after the first observation.

2) Day $0=$ The first observation day.

3) $\mathrm{L}=$ Left ovary. 4) $\mathrm{R}=$ Right ovary.

5) Characterization of ultrasonographic schemata of follicles and corpora lutea as follows;

Follicular cyst: Follicular structure more than $2.5 \mathrm{~cm}$ in diameter.

Regressive cystic follicle: Less than $2.5 \mathrm{~cm}$ in diameter.

- Medium-sized follicle: $1.0-2.4 \mathrm{~cm}$ in diameter.

Corpus luteum: Luteinized follicle without a central cavity, more than $1.5 \mathrm{~cm}$ in length.

() Luteal cyst: Luteinized follicle with a central cavity, more than $0.5 \mathrm{~cm}$ in length.

$\circ$ Regressive corpus luteum: Less than $1.5 \mathrm{~cm}$ in length.

\section{Days after the first observation}

Cow No.

Fig. 3. Ultrasonographic schemata of follicular and luteal structures in ovaries of 3 cows with interrupted nymphomania before and after treatment. See to legends for in Fig. 2 with regard to characterization of ultrasonographic schemata of follicles and corpora lutea. 


\section{Days after the first observation}

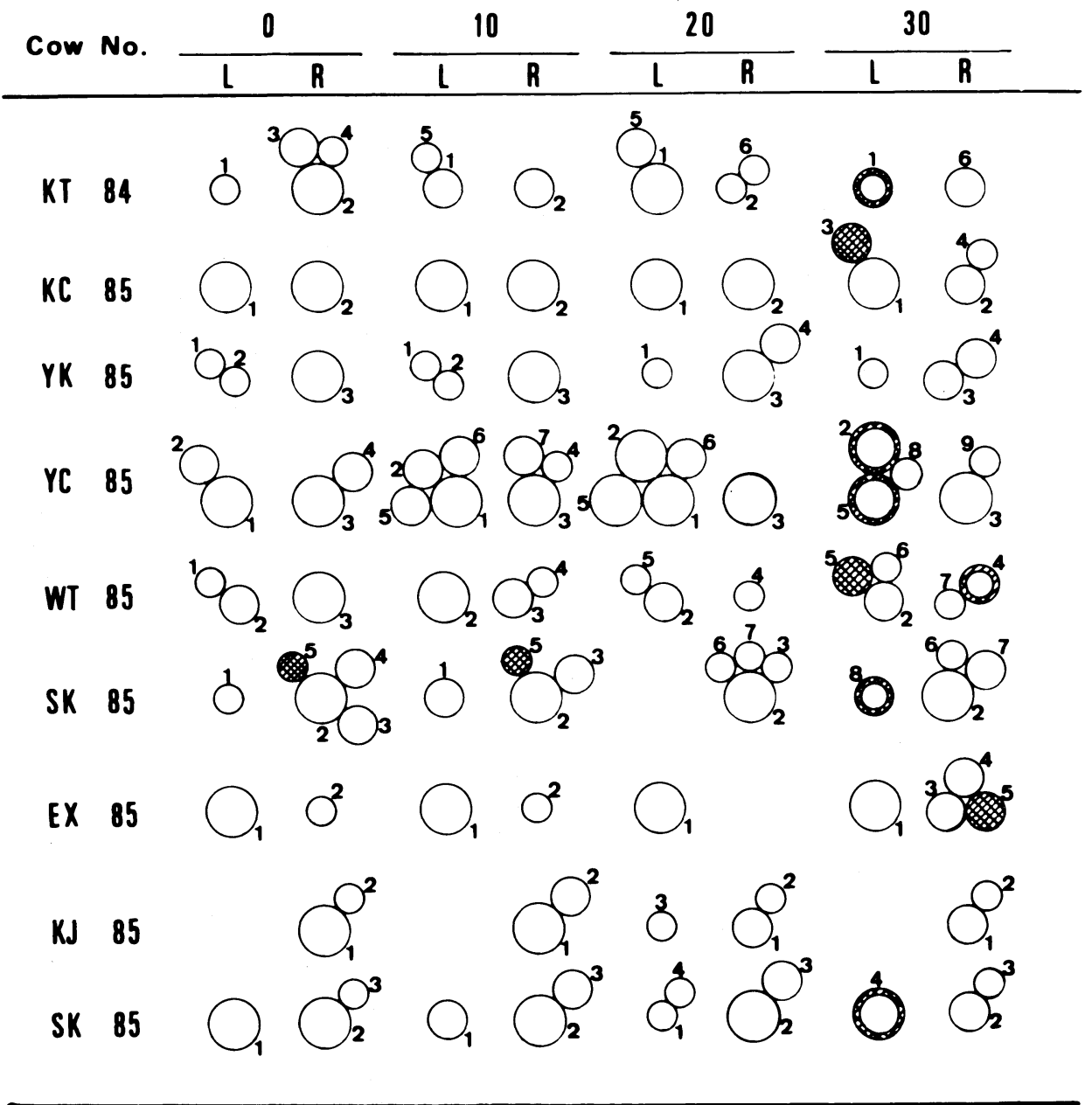

Fig. 4. Ultrasonographic schemata of follicular and luteal structures in ovaries of 9 cows with anestrus before and after treatment. See to legends for in Fig. 2 with regard to characterization of ultrasonographic schemata of follicles and corpora lutea.

present ultrasonographic investigation. The bulling symptoms of the nymphomaniac cows may be considered as the adrenal virilism (Short, 1962 ; Nessan and King, 1981) which appears to be the effects of androgenic steroids secreted mainly from the adrenal cortex. It also is well known that the adrenal cortex produces significant amount of progesterone in cattle (Wager $e t$ al., 1972). In his earlier studies on the adrenocortical function in cows with cystic ovaries, Nakao (1977) demonstrated that the cows with nymphomania had a hyperadrenocortical function, while the anestrous type of the cows had a subnormal adrenal function as investigated by a rapid ACTH stimulation test. Nakao et al. (1974) also reported that exogenous ACTH and corticosteroids significantly affected serum progesterone levels in nymphomaniac cows. Therefore, it may be assumed that high progesterone levels in skim milk in nympho- 

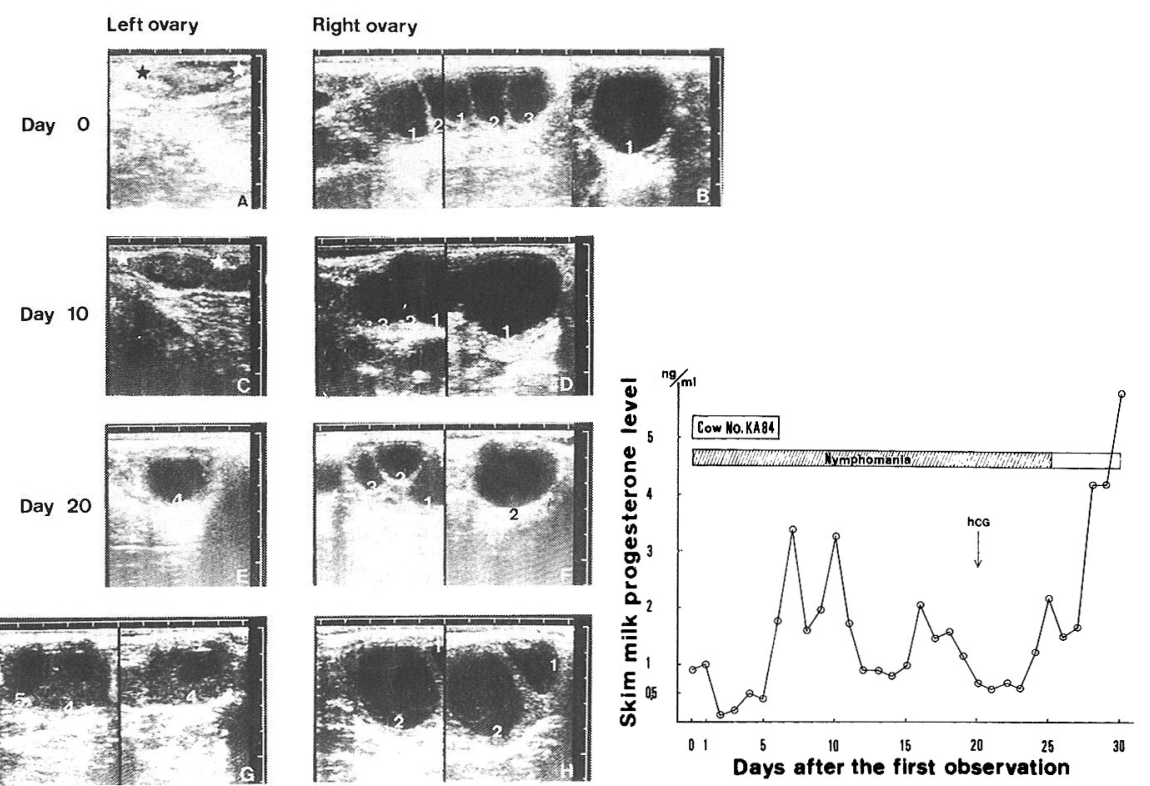

Fig. 5. The ultrasonographs of the ovaries and skim milk progesterone profile in a cow with follicular cysts showing typical nymphomaniac symptoms (Cow No. KA84).

Scale on the image is in $\mathrm{cm}$.

A) The left ovary on day 0 (Day $0=$ the day of the first observation). The ovary (length demarcated by $\star$ marks) have one weak echogeic follicle less than $0.5 \mathrm{~cm}$ in diameter. B) The right ovary on day 0 having one cystic follicle (1) and two medium-sized follicles (2,3). C) The left ovary on day 10 . The ovary (length demarcated by $\star$ marks) becames slightly larger compared as day $0 . \mathrm{D}$ ). The right ovary on day 10 having cystic follicle (2) developed from one of medium-sized follicles shown in day 0 . E) The left ovary on day 20 having a newly developed medium-sized follicle $2.0 \mathrm{~cm}$ in diameter (4). F) The right ovary on day 20. A cystic follicle undergoing atresia (1). G) The left ovsry on day 30 (10 days after hCG treatment) having a luteal cyst (4) and a newly developed medium-sized follicle (5). H) The right ovary on day 30 having one with luteinized cyst (2) and no luteinized regressive cystic follicle (1). Other medium-sized follicle (3) shown in day 20 disappear completely.

maniac cows as observed in this experiment might originate from the adrenal cortex. The assumption, however, is yet to be proved by more sophisticated experiments. In practical view, milk progesterone levels should be used cautiously for the diagnosis of ovarian cysts especially in the case of nymphomania.

In contrast, the anestrus may be encountered in cows having cystic or Graafian follicles which do not produce estrogens and androgens enough to enhance sexual behavior. In the anestrous type of cows with cystic ovaries a high progesterone level was almost always induced by hCG treatment with the presence of functional luteal tissue as observed by ultrasonography. In the present experiment, all cows with anestrus had neither corpora lutea nor luteal cysts before the hCG treatment. Three of the 9 anestrous cows maintained less than 1.0 $\mathrm{ng} / \mathrm{ml}$ and 6 had around $1.0 \mathrm{ng} / \mathrm{ml}$ of skim milk progesterone levels. After hCG treatment, all of the former 3 cows and 4 of the latter 6 cows showed the presence of luteal tissue in the follicular wall or luteinized cysts. Therefore, in anestrous cows with ovarian follicular cysts milk progesterone measurement could have the diagnostic value.

The results of the present experiment 


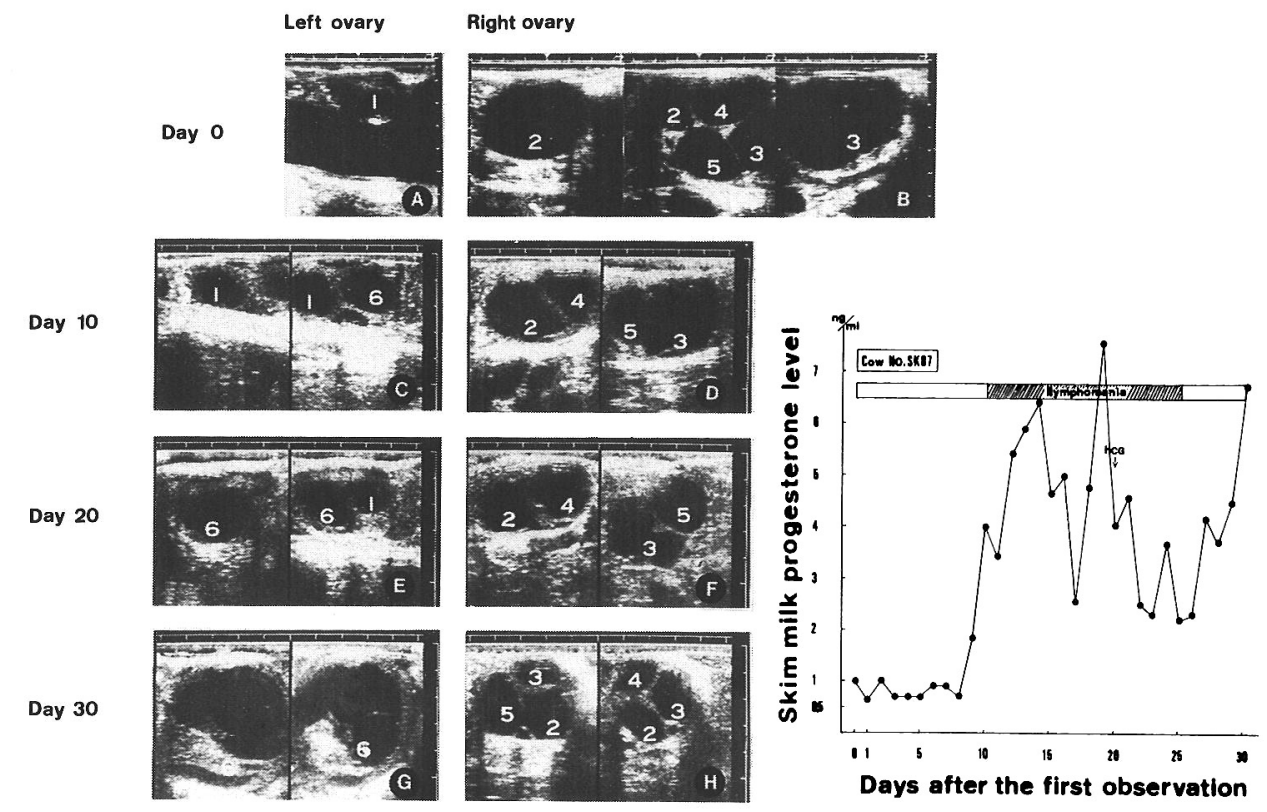

Fig. 6. The ultrasonographs of the ovaries and skim milk progesterone profile in a cow with follicular cysts showing interrupted nymphomaniac symptoms (Cow No. KA84).

Scale on the image is in $\mathrm{cm}$.

A) The left ovary on day 0 having one medium-sized follicle $1.5 \mathrm{~cm}$ in diameter (1). B) The right ovary on day 0 having two cystic follicles $(2,3)$ and two medium-sized follicles $(4,5)$. C) The left ovary on day 10 having one newly developed medium-sized follicles $2.0 \mathrm{~cm}$ in diameter $(6)$ D) The right ovary on day 10 having two cystic follicles $(2,3)$ and medium-sized follicles $(4,5)$ are approximately of same size or slightly smaller compared with day 0 . E) The left ovary day 20 having cystic follicle developed from one of medium-sized follicles shown in day $10(6)$. F) The right ovary on day 20 having two clearly decreasing cystic follicles $(2,3)$. G) The left ovary on day 30 . One cystic follicle was clearly luteinized (6). H) The right ovary on day 30 having two more decreased cystic follicles $(2,3)$ and two medium-sized follicles was not luteinized $(4,5)$.

indicate that cows with ovarian follicular cysts show dynamic morphological and functional changes of the ovaries, irrespective of the sexual behavior. Ultrasonography would be a very useful tool for accurate diagnosis of ovarian follicular cysts.

\section{References}

Edmondson AJ, Fissore RA, Pashen RL, Bondurant RH (1986) The use of ultrasonography for the study of the bovine reproductive tract. I Normal and pathological ovarian structures. Anim Reprod Sci 12: 157-165.

Kohmoto H (1987) Differentiation of ovarian cysts and analogous ovary in cows and estimation of blood progesterone level by rectal examination. $J$ Vet Clinic (289) : 39-48 (in Japanese).

Nakao T (1976) The ovarian condition diagnosed per rectum and its relations to serum concentrations of progesterone and estradiol- $17 \beta$ and prognosis in cows with cystic ovaries. Jpn J Anim Reprod 21: 147-153 (in Japanese).

Nakao T (1977) Effect of glucocorticoids and corticotropin on the periphoral blood levels of 11 hydroxycorticosteroids and progesterone and serum protein pattern in cows with cystic ovaries. Jpn J Vet Sci 39: 93-100.

Nakao T, Sato K, Ono H, Miyake M (1974) Sex steroids in the blood serum of cows with cystic ovaries in relation to the sexual behavior and the effect of treatments with corticosteroids. Jpn J Anim Reprod 20: 105-110 (in Japanese).

Nakao T, Sugihashi A, Saga N, Tsunoda N, Kawata K (1983) An improved enzyme immunoassay of progesterone applied to bovine milk. $B r$ Vet J 139: 109-118.

Nakao T, Sugihashi A, Saga N, Tsunoda N, Kawata K (1983) Use of milk progesterone enzyme im- 

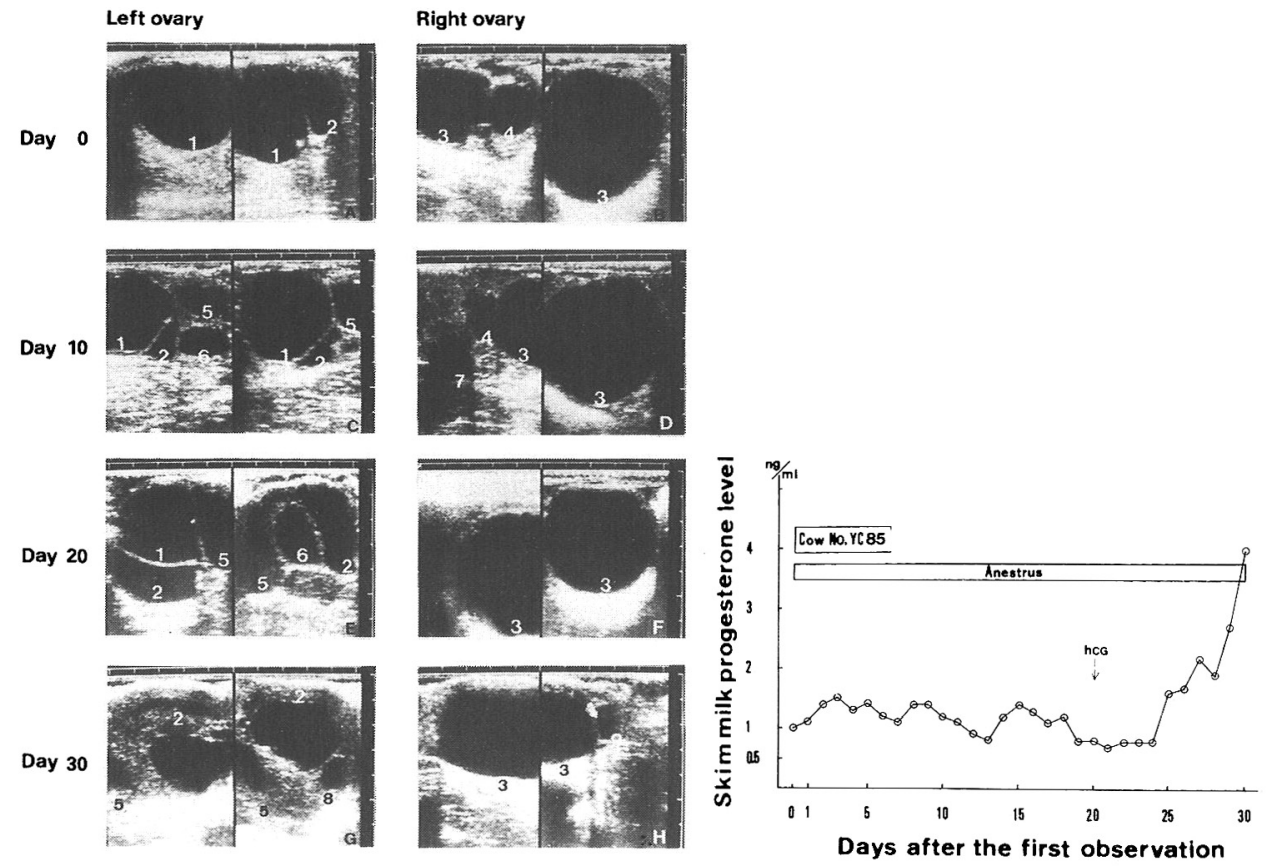

Fig. 7. The ultrasonographs of the ovaries and skim milk progesterone profile in a cow with follicular cysts showing anestrus (Cow No. YC85).

Scale on the image is in $\mathrm{cm}$.

A) The left ovary on day 0 having one cystic follicle $4.0 \mathrm{~cm}$ in diameter (1) and one medium-sized follicle (2). B) The right ovary on day 0 having one cystic follicle $5.5 \mathrm{~cm}$ in diameter (3) and one medium-sized follicle (4). C) The left ovary on day 10 having two newly developed medium-sized follicles $(5,6)$. D) The right ovary on day 10 having one newly developed medium-sized follicle (7). E) The left ovary on day 20 having two cystic follicles developed from medium-sized follicles shown in day $10(2,5)$. F) The right ovary on day 20. Two medium-sized follicles shown in day 10 (2,5) disappear completely. G) The left ovary on day 30. Two cystic follicles were clearly luteinized $(2,5)$ and one newly developed medium-sized follicle, $1.1 \mathrm{~cm}$ in diameter (8), appear. H) The right ovary on day 30. The ovary with no luteinized cysts (3) and one newly developed medium-sized follicle (9).

munoassay for differential diagnosis of follicular cyst, luteal cyst, and cystic corpus luteum in cows. Am J Vet Rec 44: 881-890.

Nessan GK, King GJ (1981) Relationship of peripheral estrogens and teststerone concentrations to sexual behavior in normal and cystic cows. Can Vel J 22: 9-11.

Sawamukai Y, Morino S, Nakao T, Kawata K (1984) Clinical and skim milk progesterone profiles in cows with follicular cysts co-existing a Graafian follicle. Jpn J Anim Reprod 30: 14-18 (in Japanese). Sawamukai Y, Saito M, Nakao T, Kawata K (1986) Clinical findings, skim milk progesterone profiles and conception rate after artificial insemination in cows bearing follicular cysts with a Graafian follicle. Jpn J Anim Reprod 32: 1-8 (in Japanese).

Seguin BE (1980) Ovarian cysts in dairy cows. In : Current Theraphy in Theriogenology (Morrow DA ed.), WB Saunders Company, Philadelphia, pp 199-204.

Short RV (1962) Steroid concentrations in normal follicular fluid and ovarian cyst fluid from cows. $J$ Reprod Fertil 4: 27-45.

Wager WC, Strohbehn RE, Haris PA (1972) ACTH, corticoids and luteal function in heifers. J Anim Sci 35: $789-793$. 


\title{
ウシ卵胞囊腫の性行動, 脱脂乳中プロジェステロン濃度並びに超音波画像による診断 および治療効果の判定
}

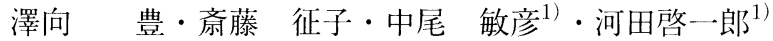 \\ 北海道農業共済組合連合会家畜臨床講習所 $\overline{\mathbf{T}} 069$ 江別市元野幌612 \\ 1)酪農学園大学獣医臨床繁殖学教室 $\quad$ T069 江別市文京台緑町582-1
}

円腸検査によって卵胞囊腫と診断されたホルスタイン 稞経济牛16頭を持続的な思牡狂症状を呈する 4 頭 (Group I)，不規則な思牡狂を発現する 3 頭（Group II）そして無発情で経過する9 頭（Group III）に区分し， 30 月栵にわたる性行動, 脱脂乳中プロジェステロン $\left(P_{1}\right)$ 湛度並びに超音波画像の变化について検討した。

1. 污奖前20日間思牡狂症状を持続していたGroup I は新たな霅腫卵胞の発育あるいは退縮が認められ, 黄体 糿㵶が纱像化されないにもかかわらず，2頭の $\mathrm{P}_{4}$ 濃度 は筫岁な增減を示した。 hCG 10,000 IU 投与後10日間

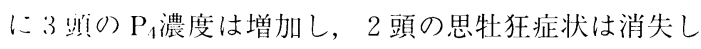
たが、新たな黄体組織が映像化されたのは 1 頭に過ぎな
かった.

2. 初診10日後から思牡狂症状を再現したGroup II は 2 頭の治療前の $\mathrm{P}_{4}$ 濃度が顕著な增減を示したが, いず れの卵巣にも黄体組織は映像化されなかった。しかし治 療後思牡狂症状が消失し, $\mathrm{P}_{4}$ 濃度が増加した 2 頭では 新たな黄体組織が映像化された。

3. 治療前20日間も無発情で経過したGroup IIIの $P_{4}$ 濃 度はいずれも低值で推移し, 黄体組織は映像化されなか ったが, 治療後10日間に明らかな $\mathrm{P}_{4}$ 濃度の増加を示し た 7 頭の卵巣では囊腫卵胞あるいは正常卵胞の黄体形成 化が認められた。 